\title{
A Reconnainsances Study to Delianate Conductive Groundwater Zone Using Resistivity Sounding in Some Part of Kwara State North- Central, Nigeria
}

\author{
S. Adamu ${ }^{1}$, A. K. Yusuf ${ }^{2}$, A.G. Kodomi ${ }^{1} \&$ I. B.Wulo ${ }^{1}$ \\ ${ }^{1}$ Department of Geology University of Maiduguri, Nigeria \\ 2 Centre for Arid Zone Studies, University of Maiduguri, Nigeria \\ Correspondence: A. K. Yusuf, Centre for Arid Zone Studies, University of Maiduguri, Nigeria. E-mail: \\ kolomiyusuf@gmail.com
}

Received: May 15, 2020

Accepted: June 222020

Online Published: August 31, 2020

doi:10.5539/jgg.v12n2p57

URL: http://dx.doi.org/10.5539/jgg.v12n2p57

\begin{abstract}
From the results, three to four electrostratigraphic layers with resistivity value ranging from 44 to $997 \mathrm{ohm} / \mathrm{m}$ and thickness ranging from 0.5 to $39.7 \mathrm{~m}$ were observed in the study area. The top loose rocks, the weathered conductive zone, the fractured basement rock and the fresh basement rock of older granite suite were encountered respectively. From this research, it can be deduce that, the thicker top soil and deeper weathered basement rock at the depth of 30 to 45 meters within this area produce a productive site for sitting future borehole. Insufficient groundwater supply in some places leading to scarcity is noticed in VES 10, VES 12 and VES 13. H, I, and A curve types are generally the most common in the area and are typical of basement complex area. Geographical Positioning System tool (model: GPSmap 76CSx), was used to locate the VES points. Fifteen VES points with electrode spacing $[\mathrm{AB} / 2]$ of 100 meters separation around Ndanaku and environs were undertaken using Schlumberger configuration. IPI 2 Win [1990-2003] Geosoft resistivity sounding software was used to model the field curves from the measured data on the field. Groundwater in the area is regarded as poor due to localized nature of the aquifer and the study aimed at addressing this scarcity of water within the area by studying the conductive zone and knows the aquifer types through resistivity sounding techniques for future drilling.
\end{abstract}

Keywords: Schlumberger Array, Basement complex, Groundwater, Electrostratigraphy, Nigeria.

\section{Introduction}

The research is part of Kwara State of Nigeria called Ndanaku underline by basement complex rock of pan African orogeny of precambrian to lower palezoic in age mostly covered by migmatite gneisses (Rahaman, 1988). Surface and groundwater resource tend to dries up during dry season within the month of April and May of every year round where groundwater is lowered in hand dug wells and boreholes with low yield. Therefore the research is aim at addressing this scarcity of water within the area by studying the conductive zone and knows the aquifer types through resistivity sounding techniques for future drilling.

Ndanaku is located within the latitudes $8^{0} 30^{\prime} \mathrm{N}$ to $8^{0} 57^{\prime} \mathrm{N}$ and longitudes $5^{0} 30 \mathrm{E}$ to $6^{0} 11^{\prime} \mathrm{E}$ Figure 1 . It is accessible through untarred road 70 kilometers away from Ilorin the Kwara State capital.

The area is characterizes by two seasons, the wet and dry season on. The onset of rainy season commences March and cessation in October, while dry season begins in November and ends in March. The amount of rainfall in the study area is about $1333.6 \mathrm{~mm}$ and the main annual minimum temperature is $21.6^{\circ} \mathrm{c}$ and the mean annual maximum temperature is $33.3^{\circ} \mathrm{c}$ while the mean annual evaporation is about $4.76 \mathrm{~mm}$. the mean annual evapotranspiration falls between $1,500 \mathrm{~mm}$ and $1,750 \mathrm{~mm}$ (Olasehinde, 1999). The vegetation cover is basically Guinea savannah interspersed with tropical forest ruminants (Esan, 1999). 


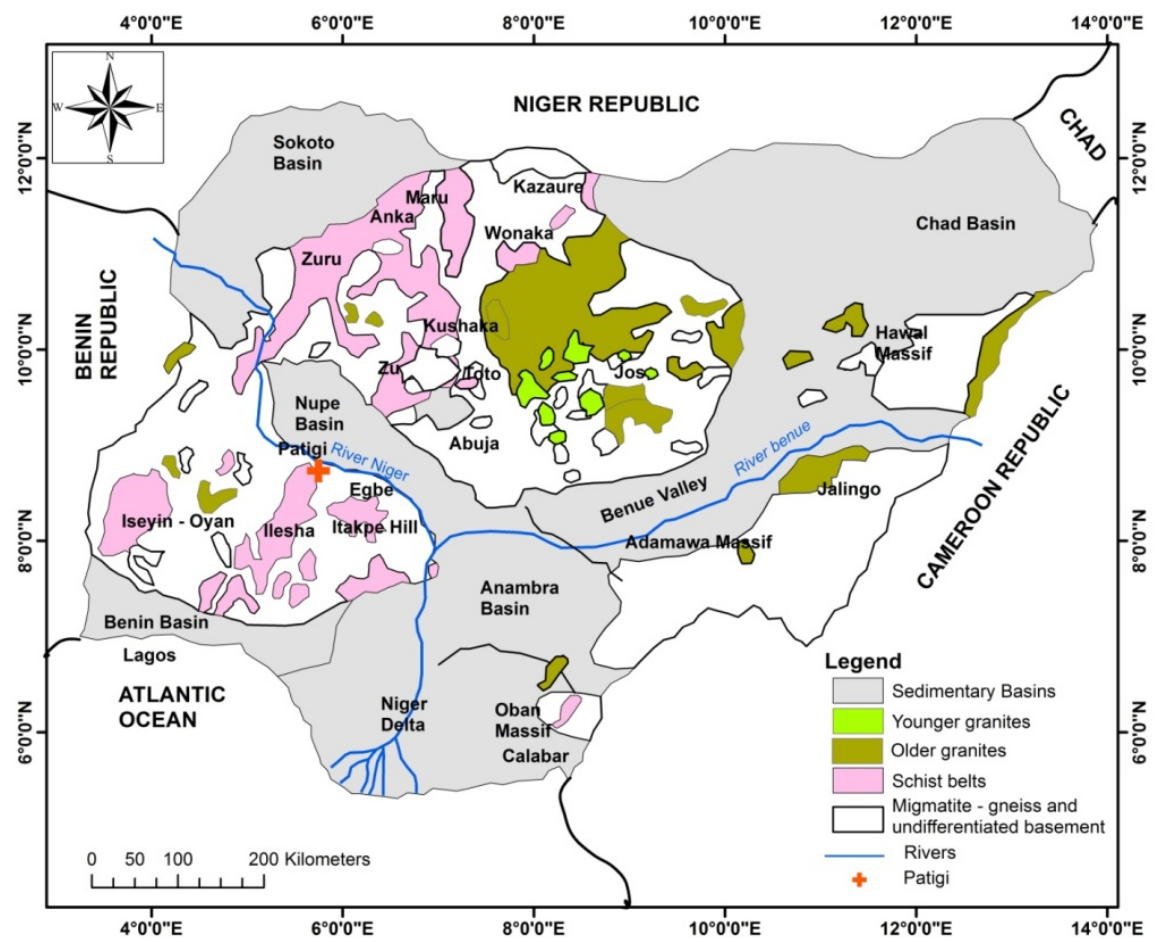

Figure 1. Location map of study Area (Source: Ministry of information Kwara State, 2019)

The topography of the area is flat in some places is consist of high relief marked by isolated hills and clays cliffs toward the south western part with various hill rock standout within the area (Cater et al 1963) border are minor hills surrounding it the prominent once being Patiyashin hills patinuwako hills found between Ndanaku and Isenlu village. The area consists of Kampe river that drained to join river Niger the drainage system exhibit dendritic pattern (Figure 2).

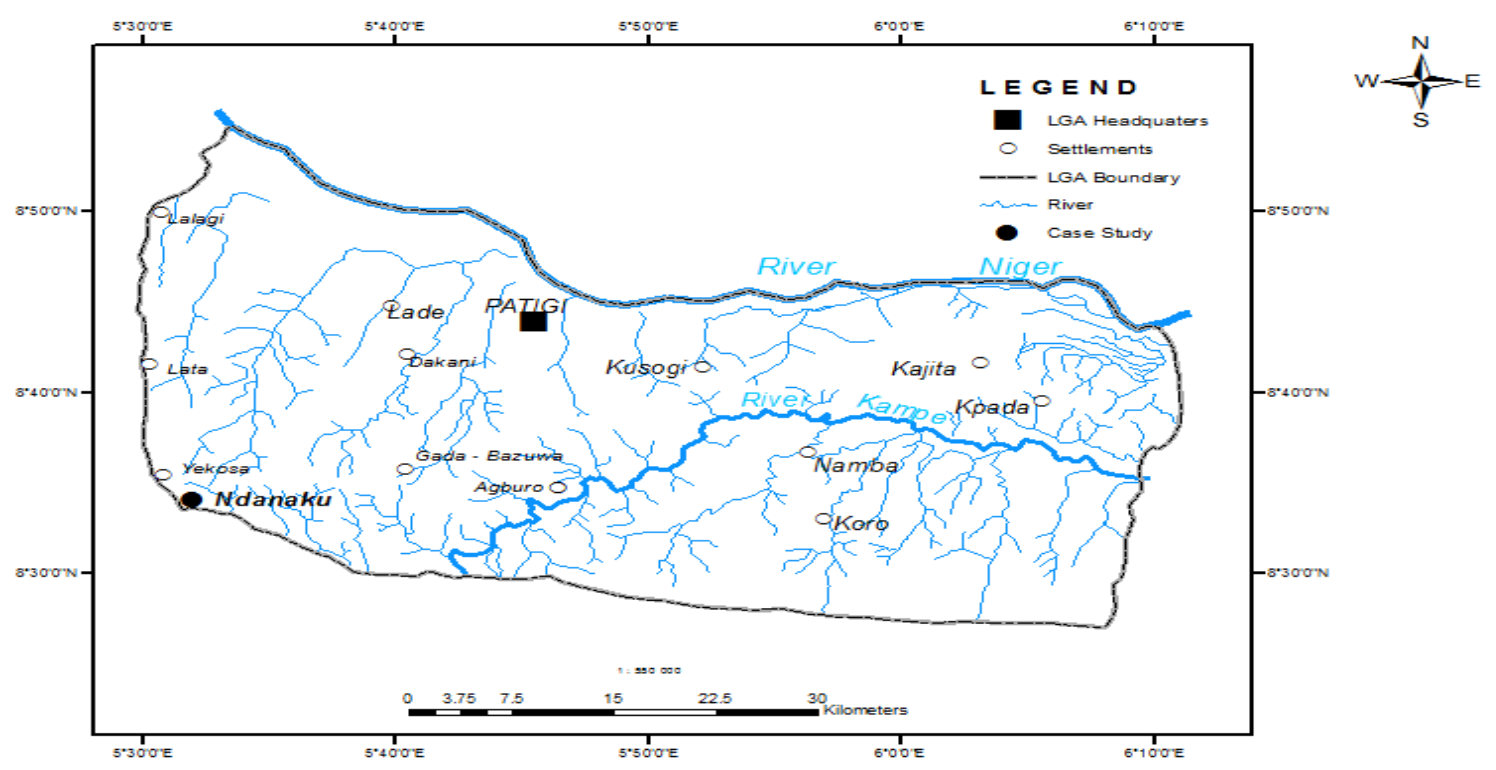

Figure 2. Drainage Pattern of the Study Area (Source: Patigi local Government, 2019) 


\section{Material and Methods}

Fifteen vertical electrical sounding (VES) points with electrode spacing $(\mathrm{AB} / 2)$ of $100 \mathrm{~m}$ were undertaken in some selected location in the study area and thirteen VES points were interpreted as seen in Figure 2. Electric current was introduced into the ground subsurface by means of two electrodes and the potential difference between the two electrodes was measured. A Global Positioning System was used to locate the VES points. Current electrodes were arranged along a straight line and the potential electrodes place midway between them $[8,2$ and 5]. Schlumberger resistivity sounding electrodes configuration was adopted for this work that provides a rapid reconnaissance in identifying high conductivity anomalies. High conductivity anomalies that might be associated with occurrence of groundwater zone were confirmed by appropriate interpretation of the obtained data using curve matching techniques and IPI 2 Win Geosoft resistivity sounding software (1990-2003). This was used to model the field curves from the field measured data and was interpreted manually. Theoretically, the interpreted results will be considered satisfactory criteria with appropriate modification of geo-electric parameters and repetition of the procedure until satisfactory fit results is achieved. The measurements obtained from the resistivity sounding is processed by software IPI 2 Win to get resistivity value and see subsurface section under sounding point. IPI $2 \mathrm{Win}$ is an open source of software. Then subsurface section interpreted based on geology map and resistivity value in purpose to know each layer lithology. The Geographical Positioning System tool (model: GPSmap 76CSx), was used because of its friendly nature with high sensitivity GPS Receiver and colour-handheld mapping ideal for both marine and outdoor use. It has electronic compass, barometric altimeter and expandable memory. It has bright, sunlight-readable colour Tft display, waterproof and easy to maintain.

\section{Results}
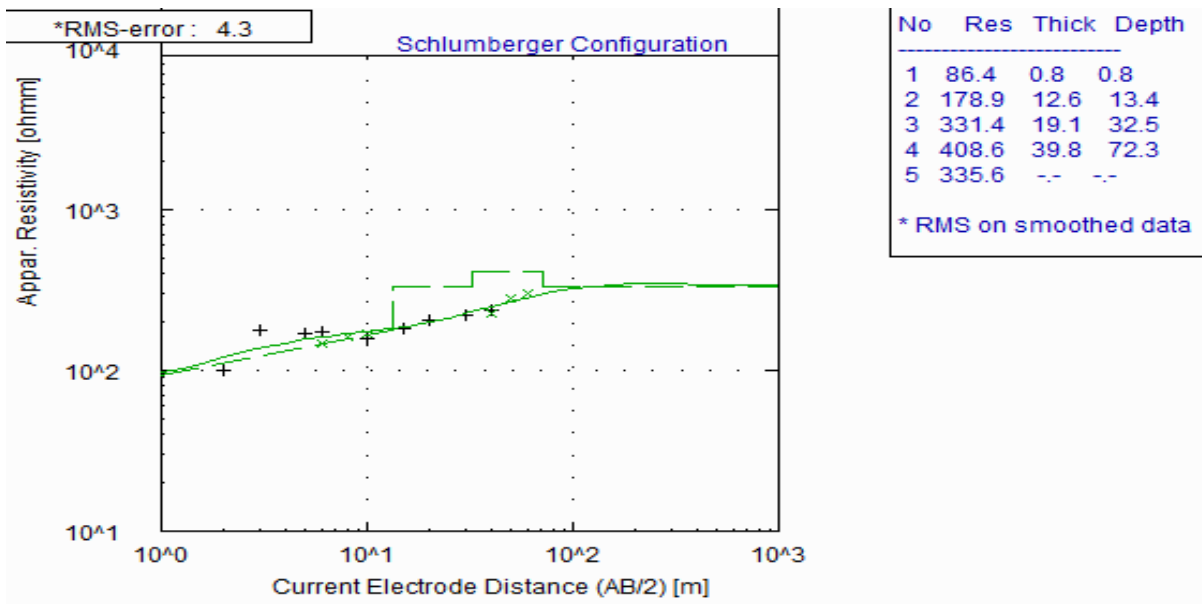

Fig 3a. VES 1 field curve for Patiyashin

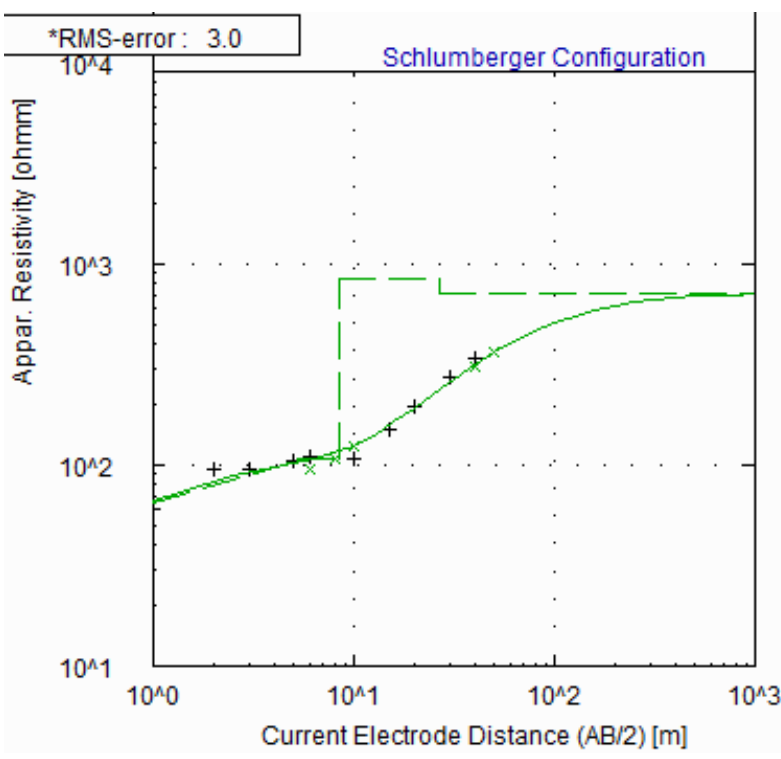

\begin{tabular}{|cccc} 
No & Res & Thick & Depth \\
\hline 1 & 54.9 & 0.5 & 0.5 \\
2 & 104.7 & 4.7 & 5.2 \\
3 & 107.2 & 3.3 & 8.5 \\
4 & 845.7 & 18.4 & 26.9 \\
5 & 712.2 & -- & -- \\
* & & & \\
RMS on smoothed data
\end{tabular}

Figure 3b. VES 2 field curve for Patinuwoko 


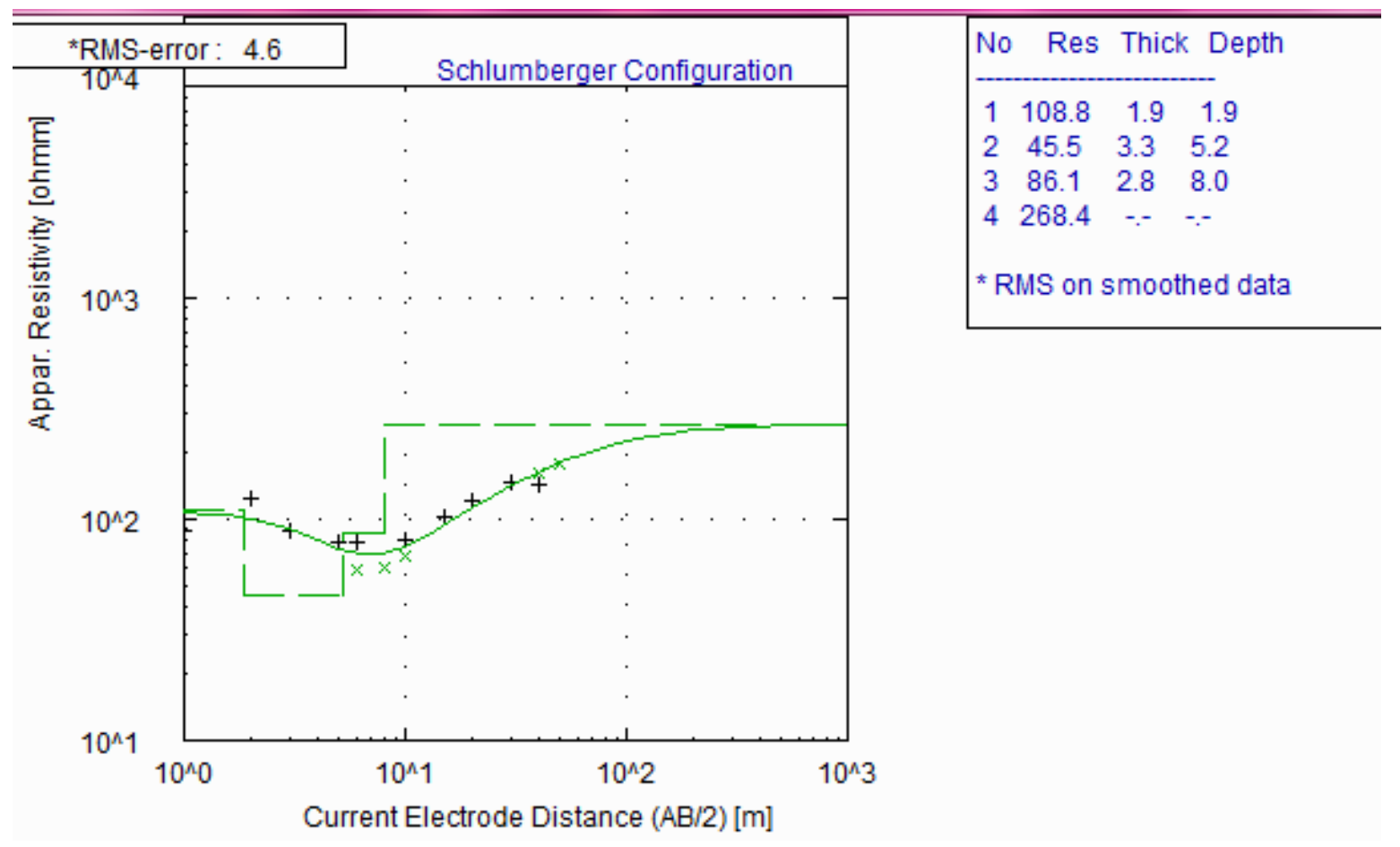

Figure 3c. VES 3 field curve for Edingaba

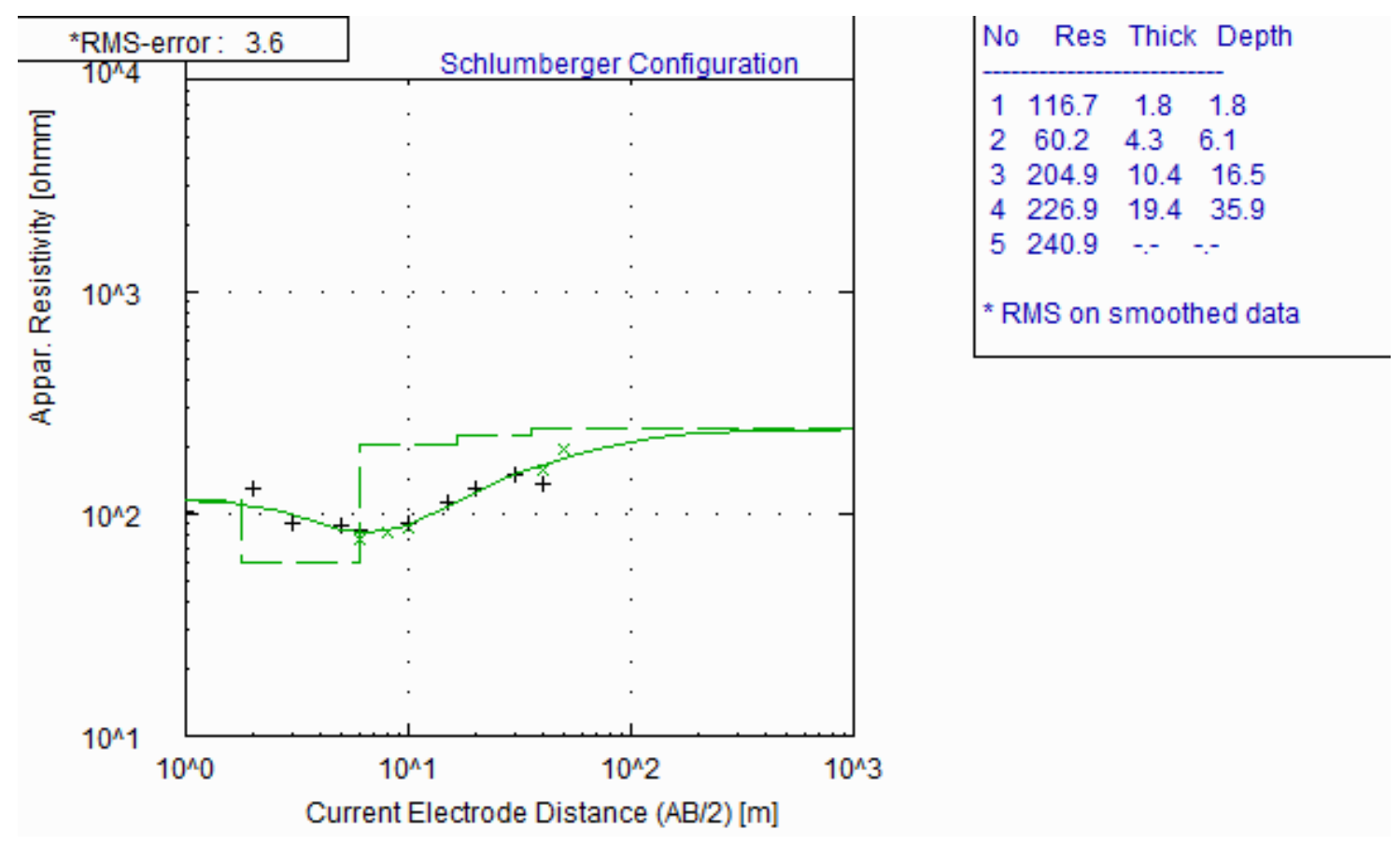

Figure 3d. VES 4 field curve for Muchitazdurugi 


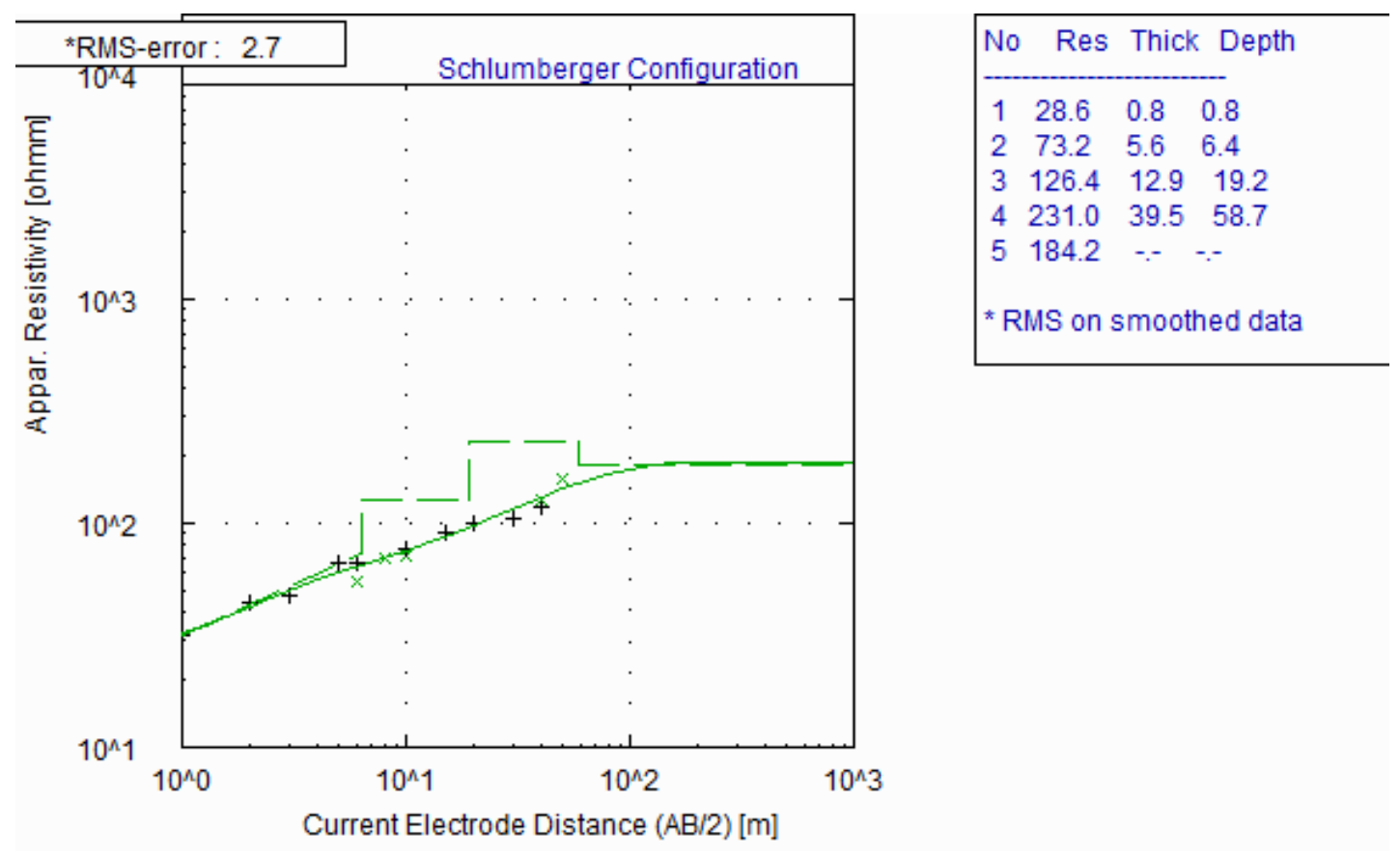

Figure 3e. VES 5 field curve for Ekosa

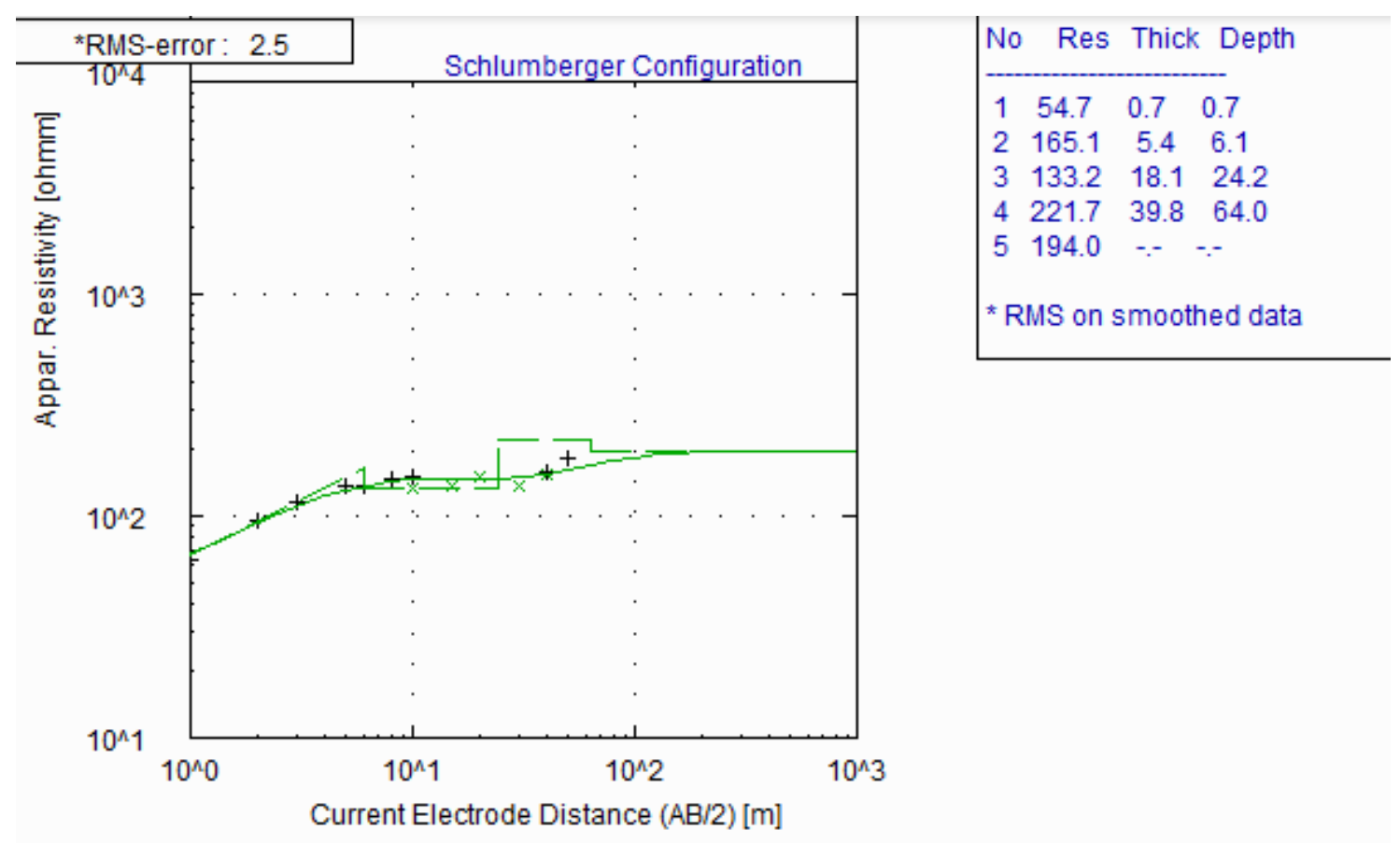

Figure 3f. VES 6 field curve for Magorota 


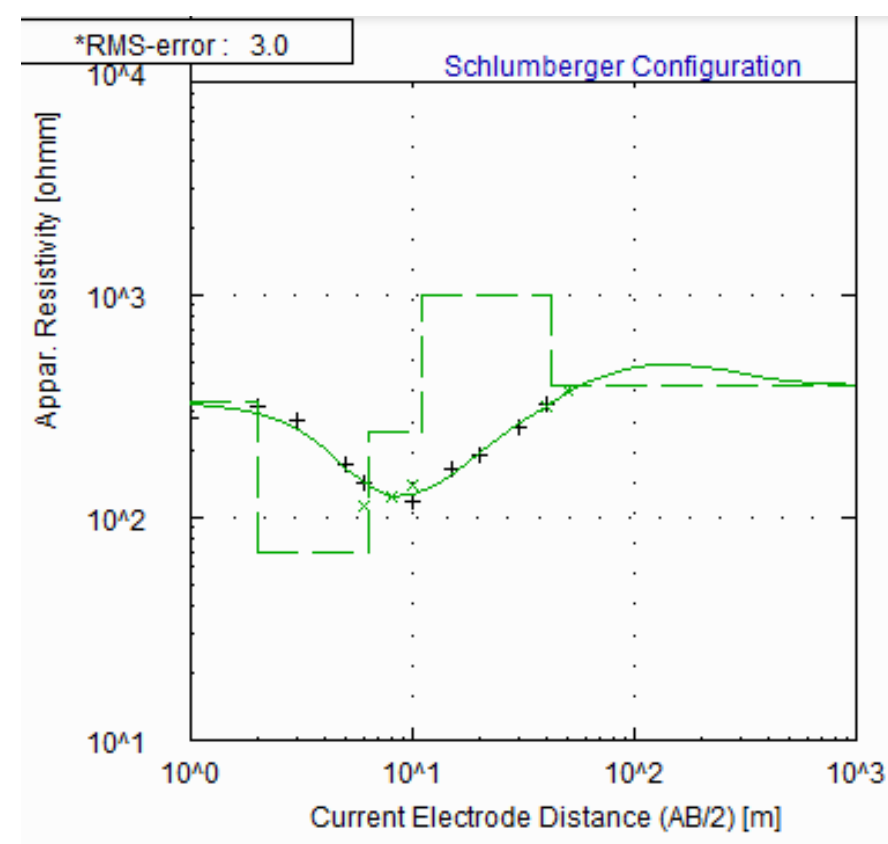

\begin{tabular}{|cccc} 
No & Res & Thick & Depth \\
\hline 1 & 328.6 & 2.0 & 2.0 \\
2 & 69.9 & 4.3 & 6.3 \\
3 & 241.5 & 4.7 & 11.0 \\
4 & 997.3 & 30.7 & 41.7 \\
5 & 388.7 & -- & -- \\
* RMS on smoothed data
\end{tabular}

Figure 3g. VES 7 field curve for Ndanuwan

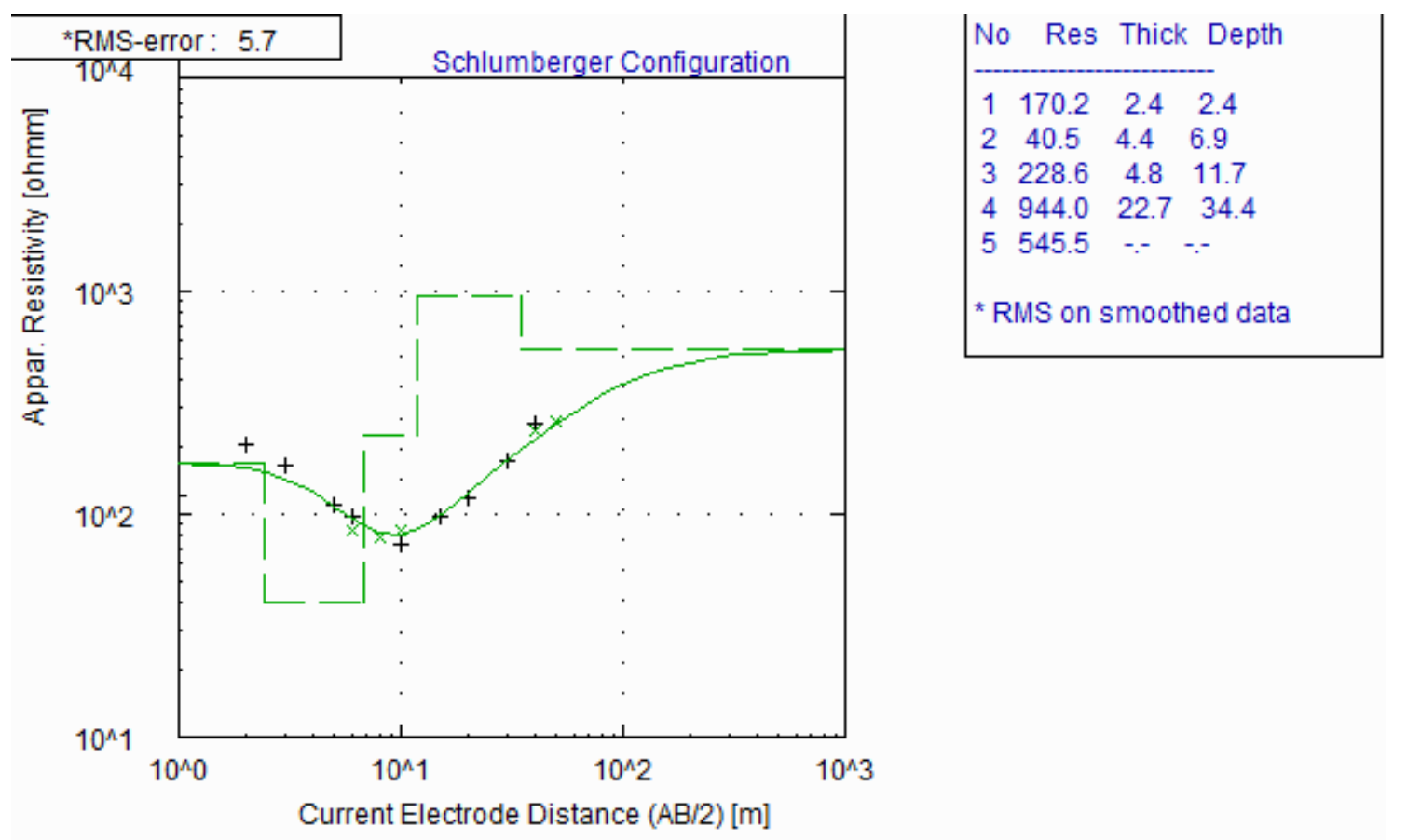

Figure 3h. VES 8 field curve for Ekanistagi 


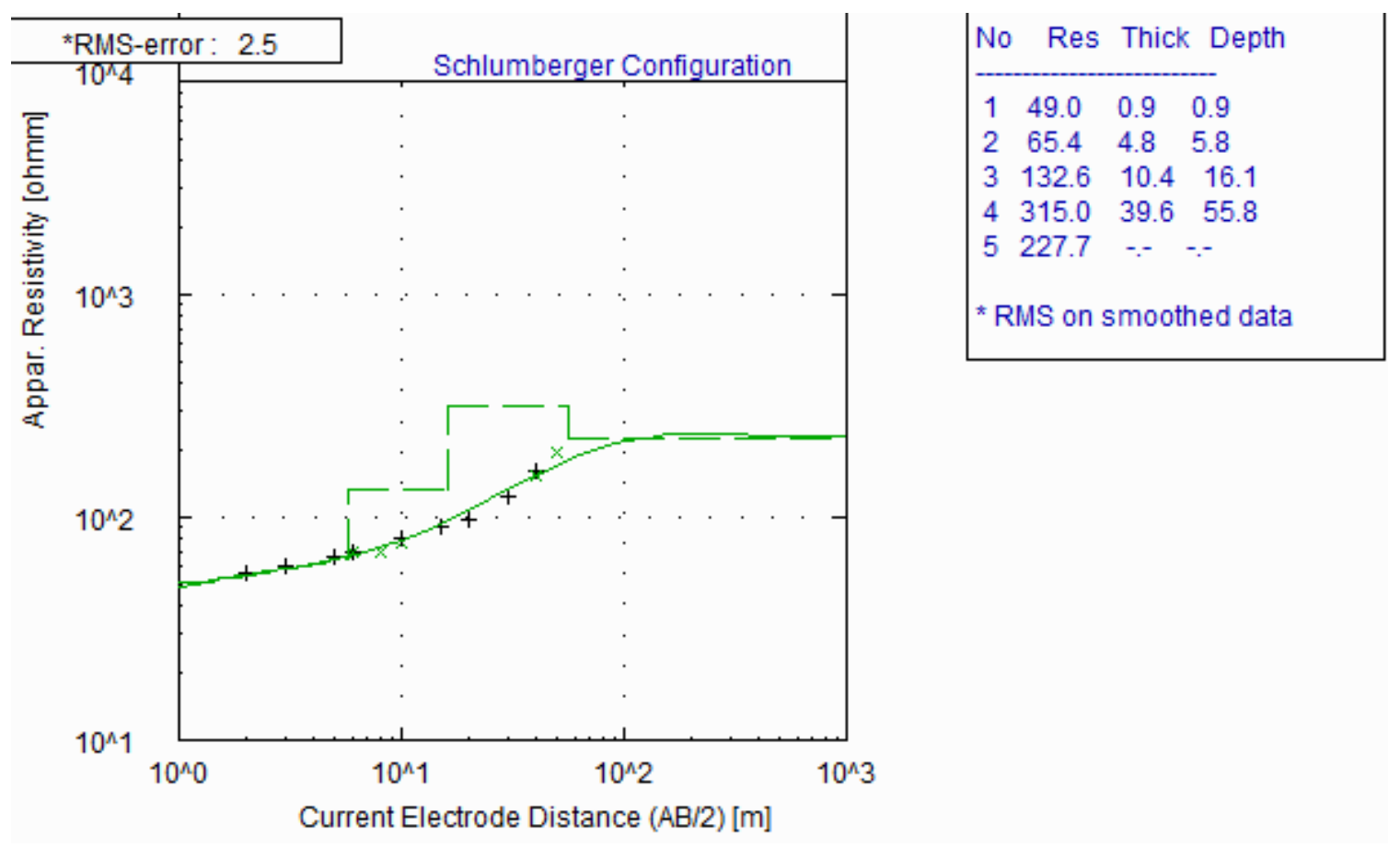

Figure 3i. VES 9 field curve for Ndamadugu

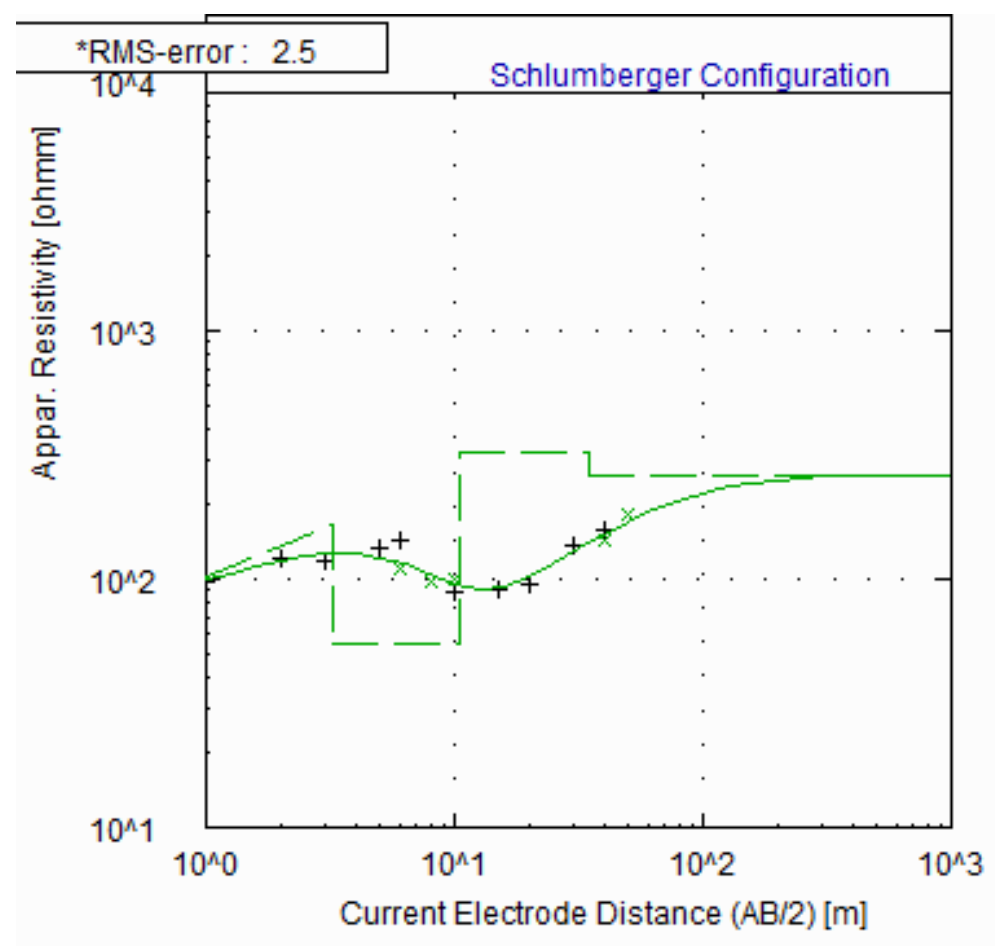

\begin{tabular}{|cccc} 
No & Res & Thick & Depth \\
\hline 1 & 92.6 & 0.8 & 0.8 \\
2 & 163.6 & 2.5 & 3.2 \\
3 & 54.6 & 7.4 & 10.6 \\
4 & 326.4 & 24.2 & 34.8 \\
5 & 263.9 & --- & --- \\
* & \multicolumn{1}{c}{ RMS on smoothed data }
\end{tabular}

Figure 3j. VES 10 field curve for Jukofiti 


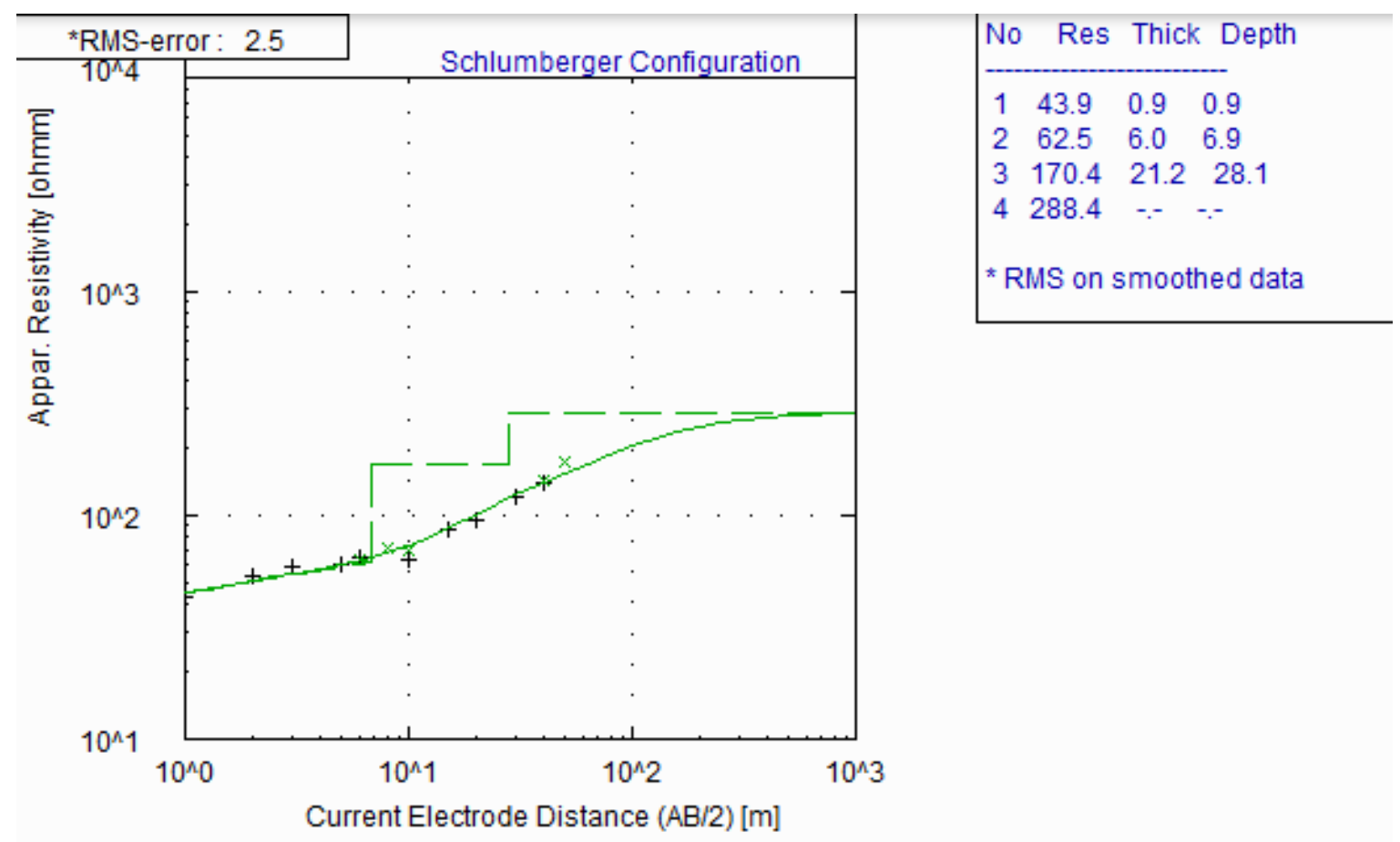

Figure 3k. VES 11 field curve for Patiyajiya

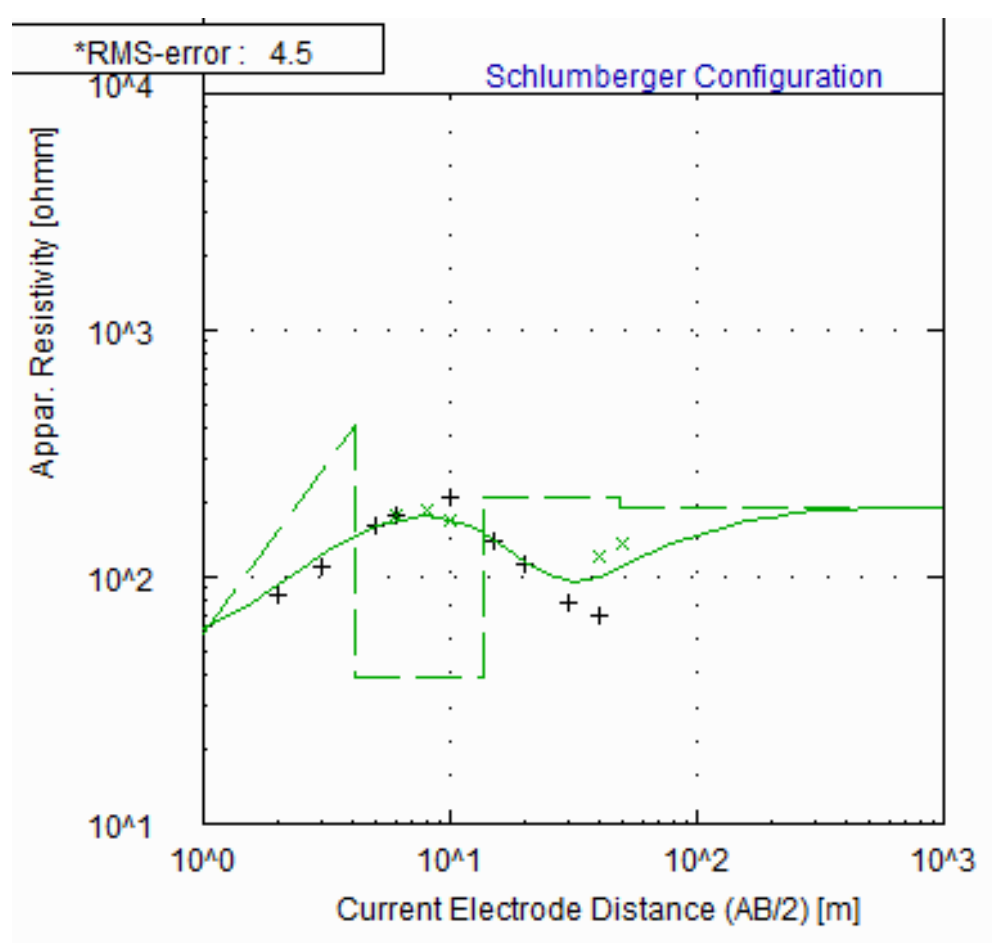

\begin{tabular}{|llll} 
No & Res & Thick & Depth \\
\hline 1 & 51.7 & 0.9 & 0.9 \\
2 & 414.0 & 3.2 & 4.1 \\
3 & 39.2 & 9.5 & 13.6 \\
4 & 210.7 & 35.1 & 48.8 \\
5 & 192.7 & --- & --- \\
* & & \\
RMS on smoothed data
\end{tabular}

Figure 31. VES 12 field curve for Ndalagba 


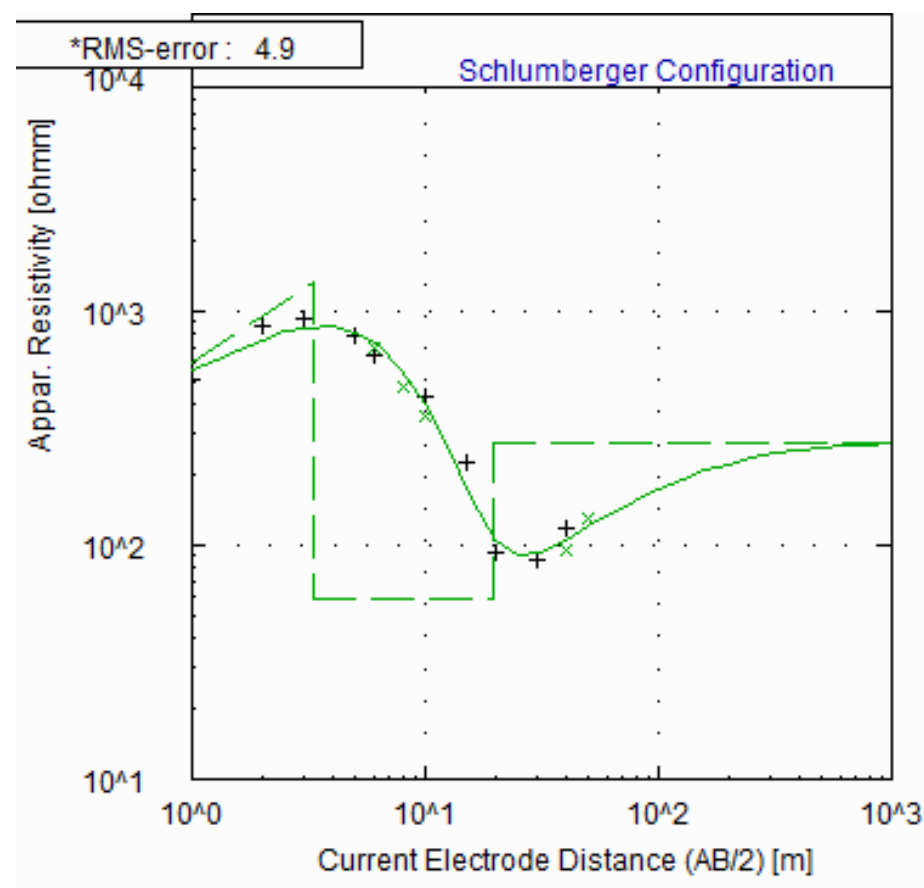

\begin{tabular}{|cccc}
\hline No & Res & Thick & Depth \\
\hline 1 & 420.2 & 0.6 & 0.6 \\
2 & 1333.4 & 2.7 & 3.3 \\
3 & 59.2 & 16.4 & 19.6 \\
4 & 277.0 &.-- & -- \\
& \\
* & \\
\end{tabular}

Figure 3m. VES 13 field curve for Egbatadzuma

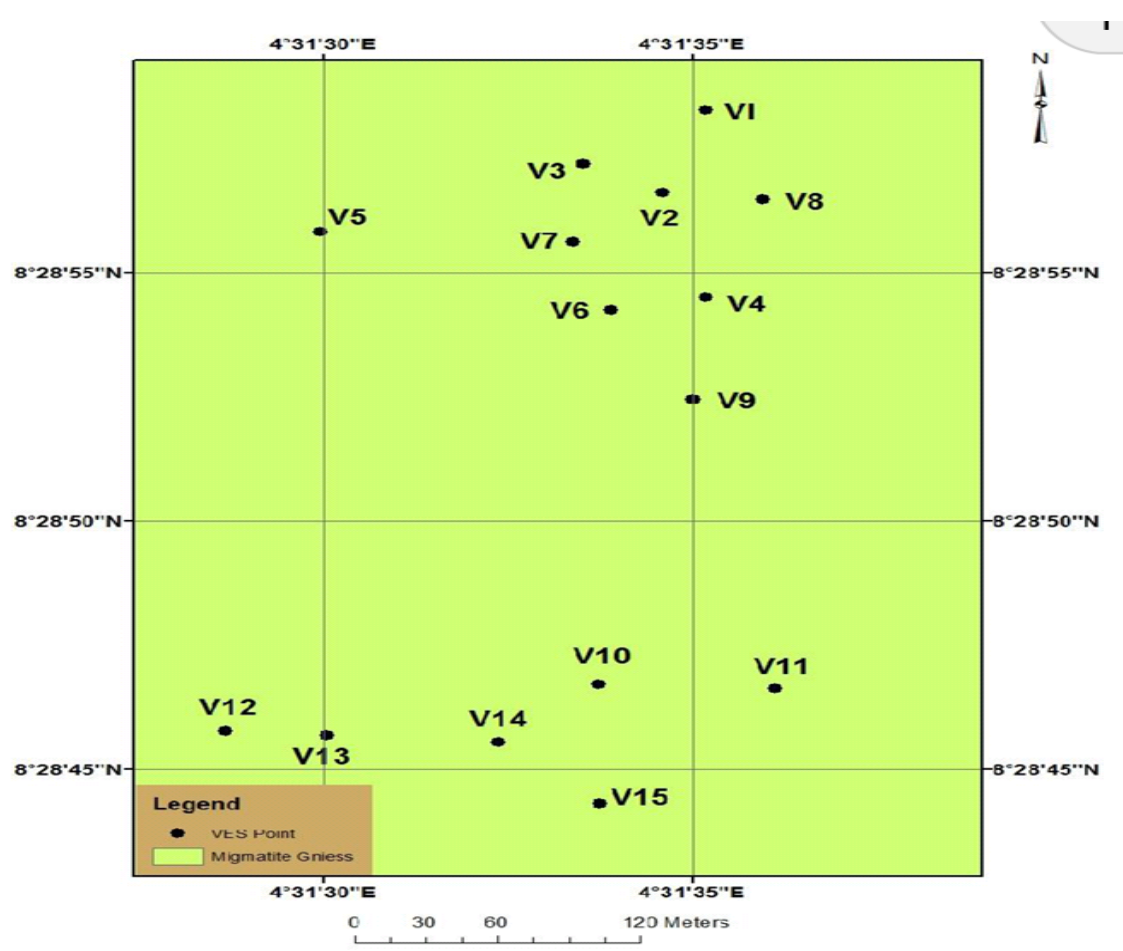

Figure 4. Location map of VES point

Table 1: Resistivity corresponding to thickness with inferred geological formation at Patiyashin VES point.

\begin{tabular}{llll}
\hline Layers & Resistivity of each layers (ohm-m) & Thickness of bed rocks (m) & Inferred geological formation \\
\hline $\mathbf{1}$ & 86.4 & 0.8 & Top soil \\
$\mathbf{2}$ & 178.9 & 12.6 & Weathered basement \\
$\mathbf{3}$ & 331.4 & 19.1 & Fractured basement \\
$\mathbf{4}$ & 408.6 & 39.8 & Fresh basement \\
\hline
\end{tabular}




\section{Discuss}

The resistivity of the rocks at various layers from the top to the bottom of fresh granite with their field curve models are presented in Figure 3a to $3 \mathrm{~m}$ below. From the results, three to four geo-electrostratigraphy successions with resistivity value ranging from 44 to $997 \mathrm{ohm} / \mathrm{m}$ and thickness ranging from 0.5 to $39.7 \mathrm{~m}$ were observed in the study area. Three to four geoelectrostratigraphic layers were encountered in the study area Table 1.

The geoelectrostratigraphic layers comprise the top loose rock, the intermediate conductive weathered layer and the highly fractured layers at the top of fresh bedrock below were encountered. Keys and McCurry (1971), Keary and Brooks (1996) and Edet et al, (1997) reported similar findings. According to Zohy (1974), Todd (1980) and Conred (1998) view that, groundwater occurrence in the basement complex rocks is limited to weathered part of the regolith and fracture basement complex rock that formed large part of the aquifer which can yield enough water for exploitation. Sani et al, (2009) is of the view that, groundwater in the basement complex is regarded as poor groundwater region due to localized nature of the aquifer compared to sedimentary terrain.

However, in the area investigated, the low resistivity value and thickly overburden of top loose rocks were observed in some VES points signifying greater potential for accumulation of groundwater. The hydrogeological condition of this research area indicates that, a greater part of the water supply can be obtained from the weathered regolith. Therefore, drilling for groundwater exploitation should be concentrated on the deeper regolith at the depth of 30 to 45 meters within this research area for optimum groundwater exploitation to avoid future drying up of wells and boreholes. The extremely large and infinite resistivity values obtained from some VES points corresponds to fresh basement rock components that are more or less solid and do not contain pore space for groundwater accumulation as presented in Figure $3 \mathrm{a}$ to $3 \mathrm{~m}$ below. Although the clay-rich minerals found in the area tend to reduce the ability for smooth movement of groundwater, thereby acting as aquicludes with high resistivity value as notice from curve matching and geoelectric stratigraphy. However, in some places, were groundwater recharge into the borehole screen or hand dug wells tapping such aquifer will find it very difficult in getting sufficient groundwater supply thereby leading to scarcity of water supply in the community that influence this research work to be undertaken which are notice in VES 10, VES 12 and VES 13 respectively.

The curve types found in the study area are generally H, I, and A type being the most common in this study area and are typical of basement complex area. It is mostly first layer correspond to topsoil which is resistive and underlain by weathered/fractured layer and finally fresh basement rock. Olasehinde, 1999 is of the same opinion that, in any basement complex terrain where resistivity sounding was carried out for groundwater exploration using the same techniques, the possible curve type are A, H and I types according to him which reflect the study area. The area is a four layered basement environment. The top soil has a resistivity value of $86.4 \mathrm{ohm}-\mathrm{m}$ and thickness of $0.8 \mathrm{~m}$ while the weathered basement has a resistivity value of $178.9 \mathrm{ohm}-\mathrm{m}$ and thickness of $12.6 \mathrm{~m}$. The fractured basement has a resistivity of $331.4 \mathrm{ohm}-\mathrm{m}$ and thickness of $19.1 \mathrm{~m}$. Fresh basement in the area has a thickness of $39.8 \mathrm{~m}$ while its resistivity value is $408.6 \mathrm{ohm}-\mathrm{m}$.

\section{Conclusion}

Groundwater investigation in some part of Kwara State has being investigated using electrical sounding to find out the conductive water bearing strata for optimum sitting of productive boreholes and hand dug wells to curtail the present scarcity of water supply in the research area. The study has deduce that, a greater concentration should be focused on thicker over burden layer and deeper weathered regolith with low resistivity value to avoid future abortive boreholes as case study of the research area with abandoned boreholes with no yields of groundwater.

\section{References}

Adamu, S., Sani, A., Joseph, M. V., \& Kwaya, M. Y. (2009). Geophysical investigation for groundwater around Gwoza area within the basement complex of NE Nigeria. Research Journal of Science, 16(1\&2), 20-30.

Carter, J. D., Barber, W., \& Tait, E. A. (1963). The geology of parts of Adamawa, Bauchi and Bornu provinces in northeastern Nigeria. Geological Survey of Nigeria Bulletin, 30.

Conred, N. L. (1998). Geophysical investigations of Ngoshe and Agapalawa areas, In files of Borno State Water Board Maiduguri, Nigeria.

Edet, A. E., \& Okereke, C. S. (1997). Assessment of hydrogeological condition in basemen aquifer of the Precambrian Oban massif, South-Eastern Nigeria. Journal of applied Geophysics, 36, 195-204.

Esan, A. (1999) The hydrogeology and hydrochemistry of groundwater in Ilorin west central Nigeria (Master's thesis). University of Ilorin, Nigeria.

Keary, P., \& Brooks, M. (1996). Introduction to geophysical exploration. London: Cambridge University Press. 
Keys, W. S., \& MacCurry, P. (1971). Application of geophysics for sitting boreholes. Water resources investigation techniques of the USGS of America. 126p.

Kwara State. (2019). Administrative map of Kwara State. In files of Kwara State Government, Nigeria.

Olasehinde, P. I., (1999b). An integrated Geologic and Geophysical Exploration Techniques for Groundwater in the Basement Complex of West Central part of Nigeria. Journal of Water Resources, 11, 46-49.

Patigi Local Government. (2019). Administrative and drainage map of the area. In files of the Patigi Local Government Kwara State, Nigeria.

Rahaman, M. A. (1988). Recent advances in the study of Basement complex of Nigeria pre-Geological time. Geological Survey of Nigeria Bulletin, 18, 11-13.

Todd, D. K. (1980). Groundwater hydrology (2nd Ed.). New York, NY: John Wiley and Sons.

Zohdy. (1974). Application of surface geophysics to groundwater investigation. Tech water resources investigation, Washington, U.S.A Geol. Survey.

\section{Copyrights}

Copyright for this article is retained by the author(s), with first publication rights granted to the journal.

This is an open-access article distributed under the terms and conditions of the Creative Commons Attribution license (http://creativecommons.org/licenses/by/4.0/). 